\title{
Discussion: Clarence Bridge, Regent"s Park, London, UK: the assessment and repair of a wrought iron lattice bridge
}

Andrew Dutton CEng, MA(Cantab), FICE, FIStructE Consultant to Hurst Peirce + Malcolm, Conservation Accredited Engineer (CARE); Hurst Peirce + Malcolm, Celtic House, London, UK (corresponding author: adutton@hurstpm.co.uk)
Ian Anderson BSC, CEng, MICE, MIStructE

East of England member, ICE Panel for Historical Engineering Works, UK

\section{Contribution by I. Anderson}

In response to the above paper on the refurbishment of Clarence Bridge in Regent's Park, London, UK, the contributor would like to add to its early history.

The Hampstead and Highgate Express for Saturday 30 August 1884 (Anon, 1884) reported that men employed by $\mathrm{Mr} \mathrm{C}$. Killingback, contractor of Camden Town, had begun foundations the previous Monday for the new footbridge over the ornamental waters of Regent's Park. The bridge would be of ornamental iron lattice girders with moulded Portland stone pilasters on either side at each end. It would be $10 \mathrm{ft}(3.05 \mathrm{~m})$ wide, of $80 \mathrm{ft}(24.38 \mathrm{~m})$ span, with $4 \mathrm{ft}(1.22 \mathrm{~m})$ heading from the water to allow boats to pass under. Some months previously, indignation meetings were held in Marylebone, agitating for more space in Regent's Park to be devoted to the public. The result of these meetings was that several acres of ground between Hanover and York gates, which had been previously kept for the exclusive use of the residents of the terraces overlooking the park, had been thrown open. The bridge was opposite Clarence gate, about midway between the two gates, and would allow direct communication from the south-west and west-central districts to the centre of Regent's Park, avoiding a circuitous route to the Zoological Society's Gardens. The Pall Mall Gazette for Monday 23 February 1885 (Anon, 1885) announced that the new bridge was opened on the previous Saturday without any ceremony. By the opening of the bridge, the public were able to obtain access between the two strips of land that were formerly enclosed, and that with other portions made a total of 20 acres of hitherto enclosed land added to the park.

\section{Author's reply}

The author would like to thank the discusser for the interest shown in the paper and providing this this historical background, which helps to put the bridge into context and shows how valued the bridge was at its time of construction.

\section{REFERENCES}

Anon (1884) Regent's Park. Hampstead \& Highgate Express, 30 August. Anon (1885) School board sites. Pall Mall Gazette, 23 February. Dutton A (2017) Clarence Bridge, Regent's Park, London, UK: the assessment and repair of a wrought iron lattice bridge. Proceedings of the Institution of Civil Engineers - Engineering History and Heritage 170(4): 189-196, https://doi.org/10.1680/jenhh.17.00012. 